\title{
The use of modern technologies to combat stripe rust in wheat
}

\section{MOHAMMAD SAYYAR KHAN ${ }^{*}$, MAZHAR ULLAH ${ }^{1}$, WAQAR AHMAD ${ }^{\mathbf{1}}$, SAYED USMAN ALI SHAH ${ }^{1}$}

${ }^{1}$ Faculty of Crop Production Sciences, Institute of Biotechnology and Genetic Engineering (IBGE), The University of Agriculture, Peshawar, Khyber Pakhtunkhwa, Pakistan

\begin{abstract}
Stripe rust or yellow rust is a serious threat to wheat production worldwide. This disease is caused by the fungus Puccinia striiformis f.sp. tritici (Pst). Currently it is controlled by the use of resistant wheat cultivars and fungicides. However, Pst can rapidly mutate to overcome the plant resistance while the excessive use of fungicides is not environment friendly. Therefore, modern tools and technologies are required to overcome this devastating disease. There are increasing evidences about the up-regulation of the fungal genes involved in the transport of ammonium and sulfur from the host, thiamine biosynthesis and cytochrome P450 enzyme are during Pst infection of wheat. Hence, one of the potential strategies to combat the stripe rust is to target these genes using RNAi technology to produce Pst resistant transgenic wheat. This will increase our understanding about the actual roles of the genes involved in ammonium and sulfur transport, thiamine biosynthesis and cytochrome P450 enzyme. Coupled with RNAi, the use of other novel technologies will be useful in developing multi-disease resistant crops. The present review is focused on the recent research breakthroughs and future challenges and opportunities towards development of rust resistant wheat varieties.
\end{abstract}

Keywords Puccinia striiformis, Biotrophic plant pathogens, HIGS, transgenic approach, RNAi.

To cite this article: KHAN MS, ULLAH M, AHMAD W, ALI SHAH SU. The use of modern technologies to combat stripe rust in wheat. Rom Biotechnol Lett. 2020; 25(1): 12811288. DOI: $10.25083 / \mathrm{rbl} / 25.1 / 1281.1288$

*Corresponding author: MOHAMMAD SAYYAR KHAN, Faculty of Crop Production Sciences, Institute of Biotechnology and Genetic Engineering (IBGE), The University of Agriculture, Peshawar, Khyber Pakhtunkhwa, Pakistan

E-mail: sayyarkhankazi@aup.edu.pk 


\section{Background}

Stripe rust or yellow rust caused by the fungus Puccinia striiformis f.sp. tritici (Pst) is one of the most devastating agricultural diseases of wheat and a serious threat to food security (CHEN [1]). It is a significant disease worldwide, including North Africa, Central Asia (WELLINGS [2]), China (WAN [3]) and United States (CHEN [4]), where epidemics have caused a reduction in the yield and quality of grain since year 2000. In many countries stripe rust poses serious threat to wheat production. For example in Australia, stripe rust is the second major threat to wheat production even though it is mainly controlled by fungicides with an annual cost of AUD\$ 127 million. The potential annual cost in the absence of control measures is around AUD\$ 180 million (WELLINGS [5]; MURRAY \& BRENNAN [6]). In Pakistan almost $70 \%$ of the wheat cultivated area is prone to stripe rust disease causing $10-17 \%$ yield loss under favorable conditions in rust susceptible cultivars (QAMAR \& al [7]; QAMAR \& al [8]).

Breeding of resistant wheat cultivars (WELLINGS [2]) and the use of fungicides is considered as the best strategies to control stripe rust (CHEN [1]). The applications of fungicides at proper time may possibly reduce losses however the low profitability of wheat production cannot sustain such costs in many dry land conditions (LOWE \& al [9]). Over the years, considerable efforts have been done for identification and introduction of resistance in the available germplasm through conventional breeding approaches. Breeding for resistance cultivars however is a difficult task and new races of the pathogens may develop to nullify host resistance. Therefore, stripe rust remains a threat to wheat production worldwide due to the rapid evolution of Pst pathotypes as a result of stepwise mutations (WELLINGS [5]). The ability of the pathogen to mutate and infect resistant wheat cultivars means that there is a need of new strategies to cope with this important disease. The use of RNAi technology has shown promising effects and might be effective in this regard (NOWARA \& al [10]; YIN \& al [11]).

Stripe rust, the pathogen and disease: Puccinia striiformis f.sp. tritici (Pst), an obligate biotrophic basidiomycete fungus, completely dependent on the host living tissue for development and reproduction (YIN \& al [12]). Pst is a macrocyclic and heteroecious pathogen producing five different types of spores and requires two hosts to complete its life cycle (JIN \& al [13]). The urediniospores produced by $P$ st during its asexual cycle are responsible for the infection of wheat. Pst may cause multiple infections in wheat during a growing season. Being a biotrophic pathogen, the Pst relationship with the host is usually persistent for weeks to months which has an important role in parasitism (FABRO \& al [14]).

Generally, rusts are among the devastating fungal disease of wheat. There are two other types of rusts, called leaf rust (brown rust) caused by Puccinia triticina and stem rust (black rust) caused by Puccinia graminis f.sp. tritici (LOWE \& al [9]). Leaf rust reduces the grain filling period and is responsible for smaller kernel size. Stem rust can damage entire wheat fields within a few weeks and leads to severe yield losses (WEGULO \& BYAMUKAMA [15]).
Pst infects mainly leaf tissues and stripe rust can develop at any point of plant development i.e from the one-leaf stage to plant maturity. The symptoms appear about one week after infection and sporulation starts two weeks postinfection. The disease can be recognized by the formation of tiny, yellow to orange colored rust pustules called uredia on the green tissues of the plant. Each uredium consists of thousands of uredinio spores (CHEN [1]). Stripes of uredia or necrosis are formed usually after stem elongation on the green tissues of adult plants. The extent of chlorosis and necrosis depends on the level of plant immunity and climate conditions (CHEN [1]) (Figure 1).

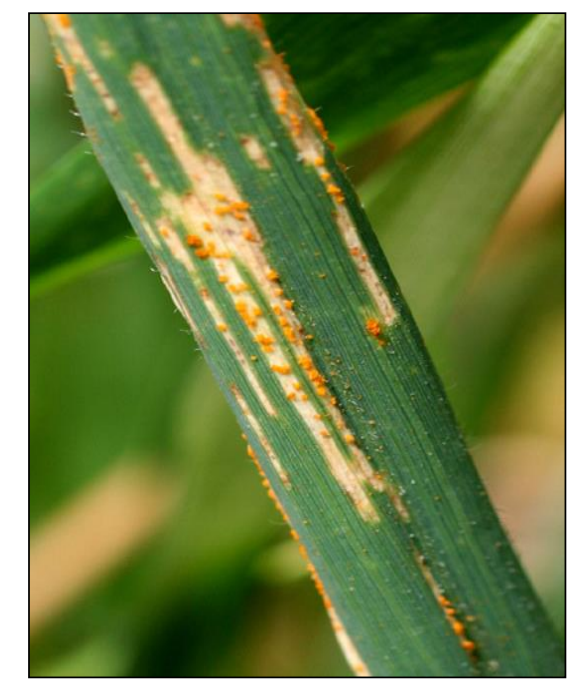

Figure 1. Stripe rust caused by $P$. striiformis f. sp. tritici on wheat (adapted from University of Georgia).

http://www.caes.uga.edu/publications/pubDetail.cfm?pk_id=7814

Pst Infection: During the asexual cycle, the uredinio spores of Pst germinate on the leaf to produce germ tubes. These tubes then develop into appressoria, which form an infection peg penetrating the leaf stomata. The infection peg develops into a substomatal vesicle, which results in the formation of a haustorial mother cell and a specialized infectious structure called the haustorium (YIN \& al [12]). The haustorium is separated from the host cytoplasm by an extrahaustorial membrane, which is adjacent to the plasma membrane of the host cell (HAHN \& MENDGEN [16]; Voegele \& al [17]).

The haustorium is an essential structure for the fungus to obtain nutrients from its host (SZABO \& BUSHNELL [18]). The space between the extrahaustorial membrane and fungal haustorial wall is known as the extrahaustorial matrix (PANSTRUGA [19]) which is enriched in vitamins (SOHN \& al [20]) and carbohydrates and plays an important role in parasitism (SZABO \& BUSHNELL [18]). Haustoria are not only the sites of nutrient uptake but are also responsible for the induction of structural changes in the host cell including cytoskeletal rearrangements, nuclear migration and chromatin condensation (HEATH [21]). Furthermore, there is an evidence that haustoria can alter host cell metabolism (VOEGELE \& MENDGEN [22]).

Biotrophic plant pathogens such as Pst secrete an array of essential virulence proteins known as effectors into the extrahaustorial matrix that are subsequently translocated 
into the host cells (KEMEN \& al 23; RAFIQI \& al [24]). The effectors are believed to play an important role in the parasitic life style of the fungus. Although very little is known about the function of fungal effectors, however it is considered that during infection they modulate plant innate immunity (PANSTRUGA \& DODDS [25]). Conversely, the plant immune system has evolved to recognize fungal effectors (BENT \& MACKEY [26]). The disease resistance genes in plants, called $R$ genes, encode immune-receptors that recognize the fungal specific effectors, called avirulence $(A v r)$ proteins, by direct or indirect association (DODDS \& RATHJEN [27]). The $A v r$ proteins act as a signal for the plant intracellular immune-receptors to induce defense mechanisms against the pathogen and often lead to a localized hypersensitive reaction and programmed cell death that restricts the pathogen to the site of infection (DODDS \& RATHJEN [27]; JONES \& DANGL [28]) (Figure 2).

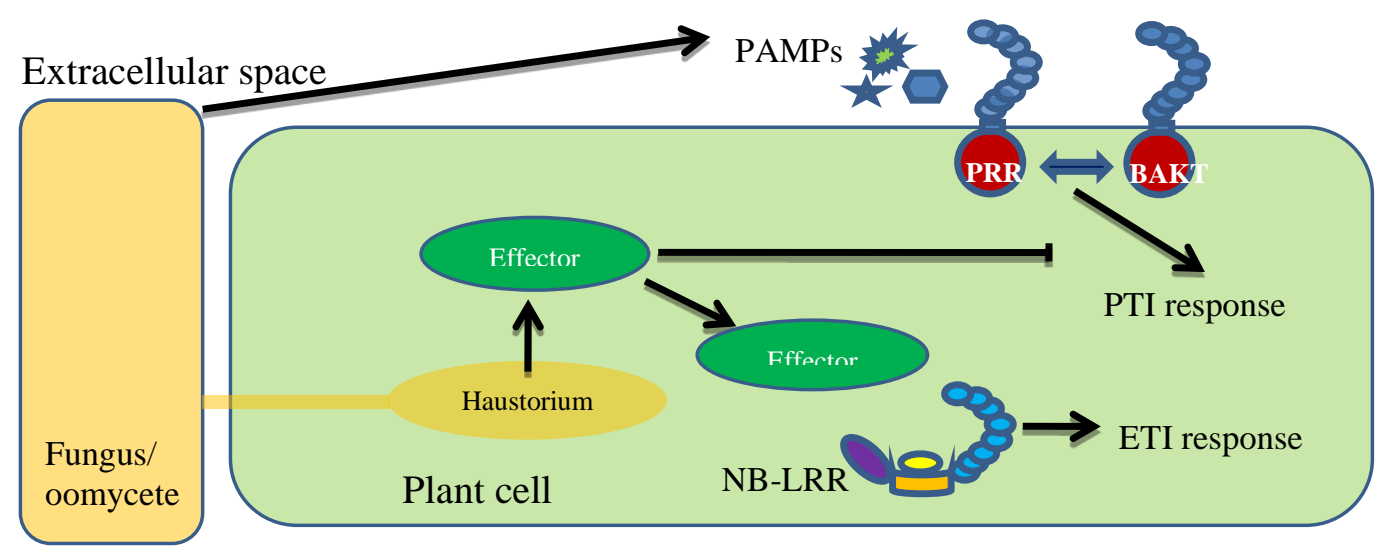

Figure 2. The fungal pathogens release some molecules, called pathogen associated molecular patterns (PAMPs), into the extracellular spaces, which are recognized by cell surface pattern recognition receptors (PRRs) and activate PAMP-triggered immunity (PTI). Fungi and oomycetes secrete effectors from haustoria, which often suppress PTI. However, effectors are recognized by intracellular receptors, called nucleotide-binding (NB)-LRR receptors, which activates effector triggered immunity (ETI) (Adapted from Dodds and Rathjen [27]).

Effector proteins are very diverse and have evolved to interfere with different aspects of the plant immune system (DODDS \& al [29]). In contrast, plant $R$ proteins belong to a small number of conserved structural classes. They can be broadly divided into two major classes. The first class of $R$ proteins consists of an intracellular nucleotide-binding leucine-rich repeat (NB-LRR) proteins, with an N-terminal Toll / interleukin-1 receptor (TIR) domain or coiled coil (CC) motif while the second class of $R$ proteins consists of an extracellular leucine rich repeat (eLRR) domain and a short transmembrane (TM) domain, either with or without an intracellular kinase domain (DODDS \& THRALL [30]; DODDS \& RATHJEN [27]). In general, immune responses of effector triggered immunity (ETI) and PAMP-triggered immunity (PTI) are similar but differ in intensity, with ETI a stronger and faster response than PTI. Moreover, PTI is only effective against non-adapted pathogens whereas ETI is active against adapted pathogens such as the flax rust fungus (Melampsoralini) of flax (DODDS \& RATHJEN [27]).

During infection the bacterial pathogens inject their effectors into the cytoplasm of plant cells using a type III secretion system that traverses the plant cell wall whereas most fungal and oomycete pathogens form a flask like structure called haustorium by penetrating the plant cell wall and invaginating the plant plasma membrane. Most fungal and oomycete effectors are secreted by the haustorium and translocated across the plant plasma membrane into the cytoplasm. Many oomycete effectors have a welldefined RxLR motif near their N-termini which appears to act as a signal for translocation (DODDS \& al [29]). Fungal effectors also appear to have N-terminal translocation signals, but do not have a conserved motif like that of oomycetes. Nevertheless, the detailed mechanism for translocation remains poorly understood for both oomycete and fungal pathogens (RAFIQI \& al [24]).

\section{Disease Management}

Plant Resistance: The most effective, economical and environmentally friendly method to control stripe rust is to grow cultivars that are genetically resistant to Pst (LINE \& CHEN [31]). Various $R$ genes active against different Pst races have been incorporated into wheat and have efficiently controlled stripe rust (WELLINGS [5]). So far seventy genes have been reported that confer resistance to different races of Pst (CHEN [1]). However, the use of $R$ gene-mediated resistance in wheat is short lived as rapid mutations in Pst allow evasion of the $R$ genes, which can lead to destructive pandemics (WELLINGS [2]).

In Australia, many new pathotypes of Pst have been detected since the original incursion of fungus in 1979 and each new pathotype was reported to be phenotypically related to a pre-existing pathotype. It has been concluded that the emergence of new pathotypes is the result of single gene mutations that are responsible for increased virulence (WELLINGS [2]). Despite of the fact that Pst spores need cool temperatures to germinate and infect (HOVMØLLER $\&$ al [32]), the new pathotypes of Pst with increased virulence have developed the ability to adapt to warmer climates and pose a serious threat to wheat production and food security worldwide (MILUS \& al [33]). With the 
instability of $R$-gene mediated resistance, there is a need for new technologies to provide options to combat stripe rust.

Use of Fungicides: An efficient system, called MoreCrop (Managerial option for reasonable economical control of rusts and other pathogens) has been developed which rely on the use of management practices, fungicides and resistant cultivars for the control of stripe rust till date (CU \& LINE [34]). In recent years fungicides have provided an economical option to control stripe rust (CHEN [1]). In developing countries the use of fungicides is a burden for farmers because of the huge costs. There are some other issues concerned with fungicides such as health problems for growers, adverse effects on the environment and the emergence of fungicide resistant strains of the pathogen, which would be a new threat to wheat production (CHEN [1]).

RNAi Technology: RNA interference (RNAi) or RNA silencing, also called as post-translational gene silencing, was first discovered in plants (FIRE \& al [35]) and exists in a wide range of eukaryotes (TIJSTERMAN \& al [36]; ULLU \& al [37]). Small interfering RNAs (siRNAs), with lengths of 21 to $28 \mathrm{bp}$ are processed from double stranded RNA of variable size and origin. siRNAs are involved in the recognition and degradation of targets such as mRNAs and viral RNA genomes. The natural RNAi silencing mechanisms in plant and eukaryotes regulate developmental programs and provide protection against invading viruses (Reviewed by SIDAHMED \& WILKIE [38]). Several in vitro studies have demonstrated that feeding of dsRNA can signal PTGS of target genes in disease causing insects (ZHANG \& al [39]), fungi (NUNES \& DEAN [40]) and nematodes (LILLELY \& al [41]). This mechanism has been deployed in the artificial gene silencing both in vitro and in vivo (MEISTER \& TUSCHI [42]) (Figure 3). Introduction and expression of dsRNA in host plants conferred protection against infections.

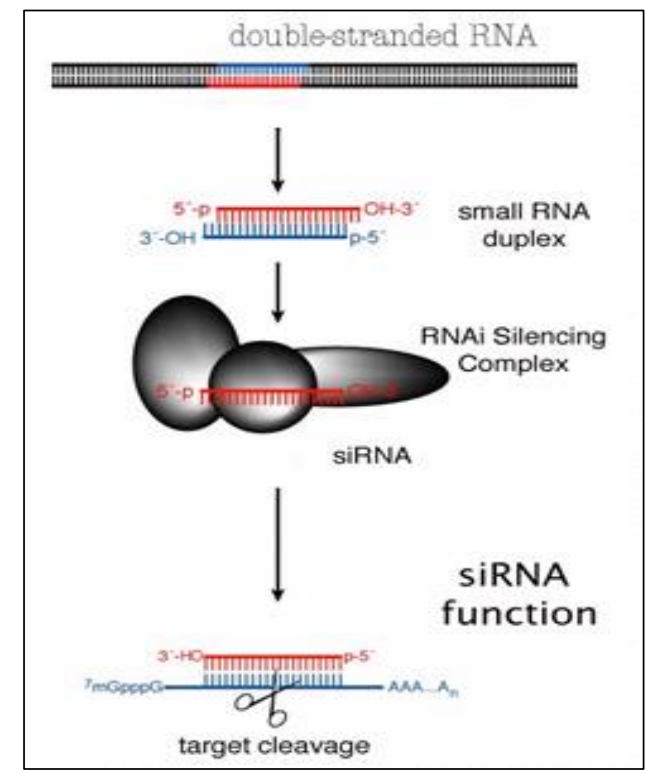

Figure 3. Model of small-RNA-guided post-transcriptional regulation of gene expression. siRNA is processed from dsRNA precursor and is involved in the formation of RNAi Silencing Complex (RISC), which leads to the degradation of target mRNA (modified from University of Fribourg. http://www.unifr.ch/biochem/index.php?id=138
In recent years, RNAi has been successfully deployed in plants to control viral diseases, using antisense or hairpin RNAi constructs against target genes (WATERHOUSE \& FUSARO [43]; SUDARSHANA \& al [44]). Additionally, RNAi has been used for the production of resistant plants against root-knot nematodes as well as Lepidoptera and Coleoptera insects. The uptake of double stranded RNA (dsRNA) or small interfering RNA (siRNA) into the mid gut of these organisms occurs by sucking or chewing of transgenic plants, which results in silencing of the targeted parasitism genes (HUANG \& al [45]; BAUM \& al [46]; MAO \& [47]).

Conversely, in fungal pathogens such as Pst, haustorium is the hub of bidirectional transport and executes the uptake of nutrients and secretion of effectors. Recent studies by (NOWARA \& al [10]) led to the finding that siRNAs along with other nutrients are transported into the obligate fungus $B$. graminis from transgenic host plants. The transgenic host plants contained RNAi constructs against fungal effectors that reduced the growth of the biotrophic B. graminis. These results suggest that an RNAibased crop protection strategy could be deployed against fungal pathogens.

Transgenic development of Host-Induced Gene Silencing (HIGS) against fungal diseases: In the last few years, several studies have documented results of HIGS against a number of pathogens in various transgenic plants. Some notable studies also demonstrated effects of HIGS against fungal diseases (Table 1). The first report came in transgenic wheat that expressed the $M L O$ gene and showed resistance against the $B$. graminis f. sp. Tritici (RIECHEN [48]). HERNANDEZ \& al [49] demonstrated the gene silencing approach by targeting the GST (Glutathione $S$-transferase) gene in tobacco. GST is a negative regulator of defense response and its silencing conferred resistance in transgenic tobacco plants against Phytophthora parasitica. Moreover, the expression of dsRNA constructs targeting fungal glucanosyl transferase genes conferred resistance in transgenic barley and wheat against powdery mildew fungus Blumeria graminis. The resistance in transgenic plants was attributed to reduced disease symptoms or haustoria formation of B. graminis (NOWARA \& al [10]). In addition to the above mentioned study, they also demonstrated HIGS based resistance to powdery mildew disease in susceptible barley cultivar Pallas that lacked the Mla10 resistance gene. The gene silencing strategy targeted the fungal effector Avra 10 gene that results in reduced number of functional haustoria inside epidermal cells in the powdery mildew susceptible cultivar. However, no such reduction in the number of functional haustoria was reported in a nearly isogenic line containing the Mlal0 gene which is considered to promote virulence. Moreover, (TINOCO \& al [50]) expressed the b-glucuronidase (GUS) gene-interfering cassette in tobacco and the transgenic plants showed silencing of the GUS transcripts in a GUSexpressing strain of necrotrophic Fusarium verticillioides during plant colonization. This study provided the evidence of concept for HIGS efficacy in phytopathogenic filamentous fungi. 
Table 1. Transgenic plants with genes conferring host-induced gene silencing against fungal infection

\begin{tabular}{|c|c|c|c|c|}
\hline Species & Host plant & Target gene & Effects & Reference \\
\hline $\begin{array}{l}\text { Blumeria graminis } \\
\quad \text { f. sp. tritici }\end{array}$ & $\begin{array}{l}\text { Triticum } \\
\text { aestivum }\end{array}$ & $M L O$ & Resistance & RIECHEN [48] \\
\hline $\begin{array}{l}\text { Phytophthora } \\
\text { parasitica var. } \\
\text { nicotianae }\end{array}$ & $\begin{array}{l}\text { Nicotiana } \\
\text { tabacum }\end{array}$ & $\begin{array}{l}\text { GST (glutathione } \\
\text { S-transferase } \\
\text { gene) }\end{array}$ & $\begin{array}{l}\text { Resistance; GST negative } \\
\text { regulator of defense response }\end{array}$ & $\begin{array}{l}\text { HERNANDEZ \& } \\
\text { al [49] }\end{array}$ \\
\hline $\begin{array}{l}\text { Blumeria } \\
\text { graminis }\end{array}$ & $\begin{array}{l}\text { Hordeum vulgare } \\
\text { and } \\
\text { Triticum } \\
\text { aestivum }\end{array}$ & $\begin{array}{l}\text { Avra10 (effector } \\
\text { gene) }\end{array}$ & $\begin{array}{l}\text { Reduced fungal development in the } \\
\text { absence of the matching resistance gene } \\
\text { Mla10 }\end{array}$ & $\begin{array}{c}\text { NOWARA \& al } \\
{[10]}\end{array}$ \\
\hline $\begin{array}{c}\text { Fusarium } \\
\text { verticillioides } \\
(=F . \text { moniliforme })\end{array}$ & $\begin{array}{l}\text { Nicotiana } \\
\text { tabacum }(\mathrm{cv} \\
\text { Xanthi) }\end{array}$ & $\begin{array}{l}\text { GUS (reporter } \\
\text { gene) }\end{array}$ & GUS silencing; proof of concept & $\underset{[50]}{\mathrm{TINOCO} \& \mathrm{al}}$ \\
\hline $\begin{array}{l}\text { Puccinia } \\
\text { striiformis } \mathrm{f} \text {. sp. } \\
\text { tritici or } \\
\text { P. graminis } \\
\text { f. sp. tritici }\end{array}$ & $\begin{array}{l}\text { Hordeum vulgare } \\
\text { and Triticum } \\
\text { Aestivum }\end{array}$ & $\begin{array}{l}\text { PSTha12J12 } \\
\text { (haustorial Pst } \\
\text { transcript) }\end{array}$ & $\begin{array}{c}\text { No obvious reductions in rust development } \\
\text { or sporulation }\end{array}$ & YIN \& al [11] \\
\hline $\begin{array}{l}\text { Phytophthora } \\
\text { parasitica }\end{array}$ & $\begin{array}{l}\text { Arabidopsis } \\
\text { thaliana }\end{array}$ & $\begin{array}{l}\text { PnPMA1 } \\
\left(H^{+} \text {-ATPase) }\right. \\
\text { and GFP } \\
\text { (reporter gene) }\end{array}$ & $\begin{array}{l}\text { Not sufficient; No reduction in GFP and } \\
\text { PnPMA1 transcripts }\end{array}$ & ZHANG \& al [51] \\
\hline $\begin{array}{l}\text { P. triticina, } \\
P . \text { graminis } \\
\text { and } P \text {. striiformis }\end{array}$ & $\begin{array}{l}\text { Triticum } \\
\text { Aestivum }\end{array}$ & $\begin{array}{l}\text { PtMAPK1 }(M A P \\
\text { kinase }), \text { PtCYC1 } \\
(\text { cyclophilin }) \\
\text { and PtCNB } \\
\text { (calcineurin B) }\end{array}$ & $\begin{array}{l}\text { Disease suppression, } \\
\text { compromising fungal growth } \\
\text { and sporulation }\end{array}$ & $\begin{array}{c}\text { PANWAR \& al } \\
{[52]}\end{array}$ \\
\hline $\begin{array}{l}\text { P. triticina, } \\
P . \text { graminis } \\
\text { and } P \text {. striiformis }\end{array}$ & - & - & - & $\begin{array}{l}\text { PANWAR \& al } \\
{[52]}\end{array}$ \\
\hline $\begin{array}{l}\text { Fusarium } \\
\text { graminearum }\end{array}$ & $\begin{array}{c}\text { Arabidopsis } \\
\text { thaliana and } \\
\text { Hordeum vulgare }\end{array}$ & $\begin{array}{l}C Y P 51 A, C Y P 51 B \\
\quad \text { and } C Y P 51 C\end{array}$ & Resistance & KOCH \& al [53] \\
\hline $\begin{array}{l}\text { Fusarium oxisporum } \\
\text { f. sp. conglutinans }\end{array}$ & $\begin{array}{l}\text { Arabidopsis } \\
\text { thaliana }\end{array}$ & $F O W 2, F R P 1$, and $O P R$ & $\begin{array}{l}\text { Low mRNA levels of the target genes. } \\
\text { Transgenic lines showed resistance and } \\
\text { high survival rates }\end{array}$ & HU \& al [54] \\
\hline
\end{tabular}

In addition to the above studies, (PANWAR \& al [52]) demonstrated the expression of hairpin RNA-generating constructs targeting the $P$. triticina pathogenicity genes Mitogen-Activated Protein Kinase 1 (PtMAPK1), Cyclophilin $(P t C Y C 1)$ or Calcineurin B $(P t C N B)$ in wheat leaves. Exposure to super infection with the $P$. triticina, the transgenic wheat leaves showed $51 \%-68 \%$ reduction in disease symptoms and a 59\%-69\% reduction in fungal biomass as compared with those of control containing the empty vector. Transgenic wheat leaves also showed reduced symptoms against exposure to stem rust or stripe rust disease. More recently, $(\mathrm{KOCH} \&$ al [53]) demonstrated that the fungal ergosterol biosynthetic genes of the CYP51 gene family provide a highly efficient strategy for combating growth and development of Fusarium species, mycotoxin-producing $F$. graminearum. They showed that the in vitro feeding of CYP3RNA, a dsRNA complementary to the three $F$. graminearum genes conferred resistance by inhibition of fungal growth. Furthermore, a recent research by (MUMBANZA \& al [55]) based on the in vitro analysis of antifungal activities of a set of synthetic dsRNAs applied to fungal spores of F. oxysporum f. sp. Cubense and Mycosphaerella fijiensis has also been reported. These fungal pathogens cause Fusarium wilt and black sigatoka in bananas.

More recently, Host-Delivered RNA interference (HD-RNAi) to partially silence three different genes (FOW2, FRP1, and OPR) of the fungus Fusarium oxysporum f. sp. Conglutinans has been reported (HU \& al [54]). dsRNA molecules targeting the fungal pathogen genes were expressed in transgenic Arabidopsis lines. The transgenic Arabidopsis lines with the dsRNA molecules showed relatively low mRNA levels of the target genes. Upon exposure to fungal infection, the transgenic lines showed high survival rates as compared to that of the wild control and exhibited enhanced resistance with delayed disease symptoms development.

Unlike the above results, lack of initiation of the HIGS-mediated gene silencing in the oomycete of the pathogen Pytophthora parasitica upon colonization of transgenic Arabidopsis with the dsRNA targeting GFP transgene or the $P$. parasitica PnPMA1 gene has also been reported previously (ZHANG \& al [51]). This is attributed to the failure of HIGS due to the lack of machinery required for the uptake of silencing in the oomycetes. On the contrary, some other studies showed onset of HIGSmediated gene silencing in oomycetes

\section{Future prospects and challenges}

Although numerous studies have been performed to investigate the fungal effectors that play essential roles in parasitism of wheat however still stripe rust remains a threat to wheat production worldwide. (NOWARA \& al [10]) reported the use of RNAi in wheat and barley to control $B$. graminis by targeting the fungal effector genes that worked to reduce fungal growth. Similarly (YIN \& al [11]) demonstrated the use of RNAi in wheat to control Pst by targeting some of the fungal genes that worked to overcome the fungal infection. However the application of 
RNAi in host plants against the fungal effector genes is not a good strategy because fungal effectors usually exist abundantly and are redundant in nature. Therefore, these effectors are individually dispensable without affecting the fitness of the pathogen (ZHANG \& al [39]).

The recent availability of rust pathogen genome sequences has led to some new discoveries of fungal genes other than effectors that are highly expressed during fungal infection and seem to play essential roles in the establishment of infection. For instance, (GARNICA \& al [56]) used next-generation sequencing (NGS) to sequence transcriptome of the wheat stripe rust pathogen and found high expression of the genes involved in nitrogen, sulphur transport, thiamine biosynthesis and Cytochrome P450 enzyme in haustoria.

Nitrogen is an essential component required for the synthesis of nitrogenous compounds that are required for protein and nucleic acid synthesis. The ammonium transported from the host is converted to glutamate and glutamine that are subsequently used for the biosynthesis of amino acids that are required for the growth and development of the fungus. Similarly sulfur is required for the synthesis of the amino acids methionine and cysteine, Coenzyme A, and iron-sulfur enzymes. Thiamine is essential for the vitamin B1 derivative thiamine pyrophosphate, which is used as a cofactor for many enzymes involved in different metabolic processes (GARNICA \& al [56]). One of the cytochrome P450s genes that is highly expressed in haustoria is a lanosterol 14 alpha-demethylase, which is involved in the synthesis of ergosterol, a fungal cell wall component. This enzyme is the target of commonly used antifungal drugs called azolez (VANDEN \& al [57]; GARNICA \& al [56]) (Figure 4).

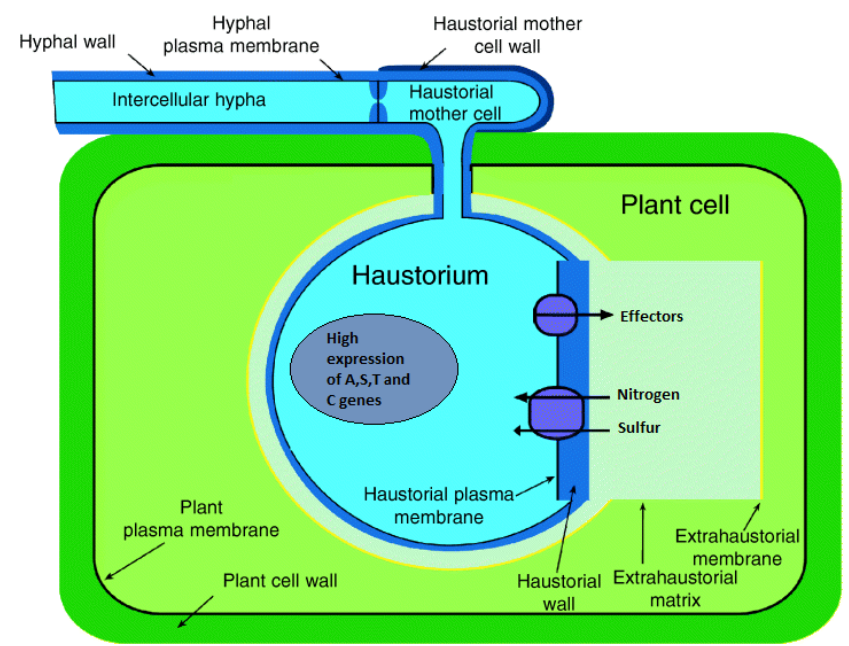

Figure 4. Schematic representation of the genes highly expressed during Pst infection in wheat. The plant genes are shown in green, while those of the fungus are of blue color.

Therefore, the focus of combating stripe rust should be on the RNAi technology using the fungal genes involved in transport of nitrogen and sulfur from the wheat, thiamine biosynthesis and cytochrome P450 enzyme. The fungus structures are shown in blue and plant structures are shown green (Figure 4). The genes involved in the transport of ammonium i.e PST79_5204 (Gene A) and sulfur i.e cysteine synthase PST79_10177 (Gene S), thiamine biosynthesis i.e THI1 and TH2 genes (Gene T) and Cytochrome P450 genes (Gene C) are highly expressed during Pst infection (GARNICA \& al [56]). The fungus releases effectors into the extra haustorial matrix which are subsequently translocated into the host cell and nutrients such as nitrogen and sulfur enter the haustorium from the host via extrahaustorial matrix. Further research efforts are required to make use of RNAi technology targeting multiple virulence-related genes instead of single genes that may confer more durable resistance.

\section{Conclusion}

Worldwide wheat production suffers substantial loses due stripe rust disease. The use of conventional methodologies such as the use of fungicides etc to counter stripe is not effective as it is a burden over country's economy and also effect the environment adversely. Based on updated literature on fungal genes responsible for parasitism in wheat can help in developing the resistant wheat cultivars against the stripe rust. RNAi technology for targeting fungal genes responsible for parasitism provides an ecofriendly platform for future combat of the stripe rust in wheat.

\section{Acknowledgements}

This work was supported by a grant from the Directorate of Science and Technology (DoST), Government of Khyber Pakhtunkhwa [grant number BT1213U04].

\section{References}

1. X.M. CHEN. Epidemiology and control of stripe rust (Puccinia striiformis f. sp. tritici) in wheat. Can. J. Plant Pathol., 27, 314-337 (2005).

2. C.R. WELLINGS. Global status of stripe rust: a review of historical and current threats. Euphytica, 179, 129-141 (2011).

3. A. WAN, Z. ZHAO, X. CHEN, Z. HE, S. JIN, Q. JIA, G. YAO, J. YANG, Y. BI, Z. Yuan, Wheat stripe rust epidemic and virulence of Puccinia striiformis f. sp. tritici in China in 2002. Plant Dis., 88, 896-904 (2004).

4. X.M. CHEN. Challenges and solutions for stripe rust control in the United States. Aus. J. Agri. Res., 58, 648-655 (2007).

5. C.R. WELLINGS. Puccinia striiformis in Australia: a review of the incursion, evolution, and adaptation of stripe rust in the period 1979-2006. Aus. J. Agri. Res., 58, 567-575 (2007).

6. G.M. MURRAY, J.P. BRENNAN. The current and potential costs from diseases of wheat in Australia. Australian Grains Research and Development Corporation Report, 69, (2009) (http://www.grdc.com.au).

7. M. QAMAR, A.D. GARDEZI, M. IQBAL. Determination of rust resistance gene complex 
Lr34/Yr18 in spring wheat and its effect on components of partial resistance. J. Phytopathol., 160, 628-636 (2012).

8. M. QAMAR, A.D. GARDAZI, RIAZ-UD-DIN, M. SOHAIL, S.H. ABBAS. Partial resistance to stripe rust and its effect on sustainability of wheat yield. Pak. J. Agric. Res., 27 (2014).

9. I. LOWE, D. CANTU, J. DUBCOVSKY. Durable resistance to the wheat rusts: integrating systems biology and traditional phenotype-based research methods to guide the deployment of resistance genes. Euphytica., 179, 69-79 (2011).

10. D. NOWARA, A. GAY, C. LACOMME, J. SHAW, C. RIDOU, D. DOUCHKOV, G. HENSEL, J. KUMLEHN, P. SC HWEIZER. HIGS: Host-Induced Gene Silencing in the obligate biotrophic fungal pathogen Blumeria graminis. Plant Cel., 22, 31303141 (2010).

11. C. YIN, J.E. JURGENSON, S.H. HULBERT. Development of a host-induced RNAi system in the wheat stripe rust fungus Puccinia striiformis $\mathrm{f}$. $\mathrm{sp}$. tritici. Mol. Plant Microbe Interact., 24:554-561 (2011).

12. C. YIN, X. CHEN, X. WANG, Q. HAN, Z. KANG, S.H. HULBERT. Generation and analysis of expression sequence tags from haustoria of the wheat stripe rust fungus Puccinia striiformis f. sp. Tritici. BMC Genom., 10, 626 (2009).

13. Y. JIN, L.J. SZABO, M. CARSON. Century-old mystery of Puccinia striiformis life history solved with the identification of Berberis as an alternate host. Phytopathol., 100, 432-435 (2010).

14. G. FABRO, J.A. DI RIENZO, C.A. VOIGT, T. SAVCHENKO, K. DEHESH, S. SOMERVILLE, M.E. ALVAREZ. Genome-wide expression profiling Arabidopsis at the stage of Golovinomyces cichoracearum haustorium formation. Plant Physiol., 146, 1421-1439 (2008).

15. S.N. WEGULO, E. BYAMUKAMA. Rust disease of wheat. University of Nebraska-Lincoln Extension, Institute of Agriculture and Natural Resources. http://www.ianrpubs.unl.edu/epublic/pages/publicatio $\underline{n D . j s p ? \text { publicationId }=1536}$ (2012).

16. M. HAHN, K MENDGEN. Characterization of in planta-induced rust genes isolated from a haustoriumspecific cDNA library. Mol. Plant Microbe Interac., 10, 427-437 (1997)

17. R.T. VOEGELE, C. STRUCK, M. HAHN, K. MENDGEN. The role of haustoria in sugar supply during infection of broad bean by the rust fungus Uromyces fabae. Proc. Nat. Acad. Sci.USA, 98, 81338138 (2001).

18. L.J. SZABO, W.R. BUSHNELL. Hidden robbers: the role of fungal haustoria in parasitism of plants. Proc. Nat. Acad. Sci., USA 98, 7654-7655 (2001).

19. R. PANSTRUGA. Establishing compatibility between plants and obligate biotrophic pathogens. Curr. Opin. Plant Biol., 6:320-326 (2003).
20. J. SOHN, R.T. VOEGELE, K. MENDGEN, M. HAHN. High level activation of vitamin B1 biosynthesis genes in haustoria of the rust fungus Uromyces fabae. Mol. Plant Microbe Interact., 13, 629-636 (2000).

21. M.C. HEATH. Signalling between pathogenic rust fungi and resistant or susceptible host plants. Ann. Bot., 80, 713-720 (1997).

22. R.T. VOEGELE, K. MENDGEN. Rust haustoria: nutrient uptake and beyond. New Phytol., 159, 93-100 (2003).

23. E. KEMEN, A.C. KEMEN, M. RAFIQI, U. HEMPEL, K. MENDGEN, M. HAHN, R.T. VOEGELE. Identification of a protein from rust fungi transferred from haustoria into infected plant cells. Mol. PlantMicrobe Interact., 18, 1130-1139 (2005).

24. M. RAFIQI, P.H. GAN, M. RAVENSDALE, G.J. LAWRENCE, J.G. ELLIS, D.A. JONES, A.R. HARDHAM, P.N. DODDS. Internalization of flax rust avirulence proteins into flax and tobacco cells can occur in the absence of the pathogen. Plant Cel., 22, 2017-2032 (2010).

25. R. PANSTRUGA, P.N. DODDS. Terrific protein traffic: the mystery of effector protein delivery by filamentous plant pathogens. Sci., 324, 748-750 (2009).

26. A.F. BENT, D. MACKEY. Elicitors, effectors, and R genes: the new paradigm and a lifetime supply of questions. Ann. Rev. Phytopathol., 45, 399-436 (2007).

27. P.N. DODDS, J.P. RATHJEN. Plant immunity: towards an integrated view of plant-pathogen interactions. Nat. Rev. Genet., 11, 539-548 (2010).

28. J.D. JONES, J.L. DANGL. The plant immune system. Nat., 444, 323-329 (2006).

29. P.N. DODDS, M. RAFIQ, P.H.P. GAN, A.R. HARDHAM, D.A. JONES, J.G. ELLIS. Effectors of biotrophic fungi and oomycetes, pathogenicity factors and triggers of host resistance. New Phytologist, 183, 993-1000 (2009).

30. P.N. DODDS, P. THRALL. Recognition events and host-pathogen co-evolution in gene-for-gene resistance to flax rust. Funct. Plant Biol., 36, 395-408 (2009).

31. R.F. LINE, X.M. CHEN. Successes in breeding for and managing durable resistance to wheat rusts. Plant Dis., 79, 1254-1255 (1995).

32. M.S. HOVMØLLER, S. WALTER, A.F. JUSTESEN. Escalating threat of wheat rusts. Sci., 329, 369 (2010).

33. E.A. MILUS, K. KRISTENSEN, M.S. HOVMOLLER. Evidence for increased aggressiveness in a recent widespread strain of Puccinia striiformis f. sp. tritici causing stripe rust of wheat. Phytopathol., 99, 89-94 (2009).

34. R.M. CU, R.F. LINE. An expert advisory system for wheat disease management. Plant Dis., 78, 209-215 (1994).

35. A. FIRE, S. XU, M.K. MONTGOMERY, S.A. KOSTAS, S.E. DRIVER, C.C. MELLO. Potent and specific genetic interference by double-stranded RNA in Caenorhabditis elegans. Nat., 391, 806-811 (1998). 
36. M. TIJSTERMAN, R.F. KETTING, R.H. PLASTERK. The genetics of RNA silencing. Ann. Rev. Genet., 36, 489-519 (2002).

37. E. ULLU, C. TSCHUDI, T. CHAKRABORTY. RNA interference in protozoan parasites. Cell Microbiol., 6, 509-519 (2004).

38. A.M. SIDAHMED, B. WILKIE. Endogenous antiviral mechanisms of RNA interference: a comparative biology perspective. Meth. Mol. Biol., 623, 3-19 (2010).

39. H. ZHANG, H.C. LI, X.X. MIAO. Feasibility, limitation and possible solutions of RNAi-based technology for insect pest control. Insect Sci., 20, 15-30 (2013).

40. C.C. NUNES, R.A. DEAN. Host-induced gene silencing: a tool for understanding fungal host interaction and for developing novel disease control strategies. Mol. Plant. Pathol., 13, 519-529 (2012).

41. C.J. LILLEY, L.J. DAVIES, P.E. URWIN. RNA interference in plant parasitic nematodes: a summary of the current status. Parasitol., 139, 630-640 (2012).

42. G. MEISTER, T. TUSCHL. Mechanisms of gene silencing by double-stranded RNA. Nat., 431, 343-349 (2004).

43. P.M. WATERHOUSE, A.F. FUSARO. Plant science. Viruses face a double defense by plant small RNAs. Sci., 313, 54-55 (2006).

44. M.R. SUDARSHANA, G. ROY, B.W. FALK. Methods for engineering resistance to plant viruses. Meth. Mol. Biol., 354, 183-195 (2007).

45. G. HUANG, R. ALLEN, E.L. DAVIS, T.J. BAUM, R.S. HUSSEY. Engineering broad root-knot resistance in transgenic plants by RNAi silencing of a conserved and essential root-knot nematode parasitism gene. Proc. Nat. Acad. Sci., USA 103, $14302-14306$ (2006).

46. J.A. BAUM, T. BOGAERT, W. CLINTON, G.R. HECK, P. FELDMANN, O. ILAGAN, S. JOHNSON, G. PLAETINCK, T. MUNYIKWA, M. PLEAU, T. VAUGHN, J. ROBERTS. Control of coleopteran insect pests through RNA interference. Nat. Biotechnol., 25, 1322-1326 (2007).

47. Y.B. MAO, W.J. CAI, J.W. WANG, G.J. HONG, X.Y. TAO, L.J. WANG, Y.P. HUANG, X.Y. CHEN. Silencing a cotton bollworm P450 monooxygenase gene by plant-mediated RNAi impairs larval tolerance of gossypol. Nat. Biotechnol., 25, 1307-1313 (2007).

48. J. RIECHEN. Establishment of broad-spectrum resistance against Blumeria graminis f. sp. tritici in Triticum aestivum by RNAi-mediated knock-down of MLO. J. Verbrauch. Lebensm., 2, 120 (2007).

49. I. HERNANDEZ, O. CHACON, R. RODRIGUEZ, R. PORTIELES, Y.L.M. PUJOL, O. BORRASHIDALGO. Black shank resistant tobacco by silencing of glutathione S-transferase. Biochem, Biophys. Res. Commun., 387, 300-304 (2009).

50. M.L. TINOCO, B.B DIAS, R.C. DALL'ASTTA, J.A. PAMPHILE, F.J. ARAGAO. In vivo trans-specific, gene silencing in fungal cells by in planta expression of a double-stranded RNA. BMC Biol., 31, 27 (2010).

51. M. ZHANG, Q. WANG, K. XU, Y. MENG, J. QUAN, W. SHAN. Production of dsRNA sequences in the host plant is not sufficient to initiate gene silencing in the colonizing oomycete pathogen Phytophthora parasitica., PLoS One, 6, 1-10 (2011).

52. V. PANWAR, B. MCCALLUM, G BAKKEREN. Endogenous silencing of Puccinia triticina pathogenicity genes through in planta-expressed sequences leads to suppression of rust diseases on wheat. Plant J., 73, 521-532 (2013).

53. A. KOCH, N. KUMAR, L. WEBER, H. KELLER, J. IMANI, K.H. KOGEL. Host-induced gene silencing of cytochrome P450 lanosterol C14ademethylaseencoding genes confers strong resistance to Fusarium species. Proc. Nat. Acad. Sci., USA 110, 19324-19329 (2013).

54. Z.U. HU, N. PAREKH, Y. MARUTA, TRUSOV, J.R. BOTELLA. Down-regulation of Fusarium oxysporum endogenous genes by Host-delivered RNA interference enhances disease resistance. Front. Chem., 3, 1 (2015)

55. F.M. MUMBANZA, A. KIGGUNDU, G. TUSIIME, W.K. TUSHEMEREIRWE, C. NIBLETT, A. BAILEY. In vitro antifungal activity of synthetic dsRNA molecules against two pathogens of banana, Fusarium oxysporum f. sp. Cubense and Mycosphaerella fijiensis. Pest Manage. Sci., 69, 1155-1162 (2013).

56. D.P. GARNICA, N.M. UPADHYAYA, P.N. DODDS, J.P. RATHJEN. Strategies for wheat stripe rust pathogenicity identified by transcriptome sequencing. PLOS ONE 8, 6 (2013).

57. B.H. VANDEN, P. MARICHAL, J. GORRENS, M.C. COENE. Biochemical basis for the activity and selectivity of oral antifungal drugs. Brit. J. Clinic Pract. Suppl., 71, 41-46 (1990). 